\title{
Parity as failure determinants of labor induction in Bangka Belitung
}

\author{
Dina Delvin Anggriani, ' Lilik Herawati, ${ }^{2}$ Ernawati $^{3}$ \\ 'Midwifery Studies Program, Faculty of Medicine, Universitas Airlangga Surabaya \\ ${ }^{2}$ Department of Physiology, Faculty of Medicine, Universitas Airlangga Surabaya \\ ${ }^{3}$ Department of Obstetrics and Gynecology, Faculty of Medicine, Universitas Airlangga Surabaya
}

\section{ABSTRAK}

Tujuan: mengetahui faktor yang mempengaruhi kegagalan induksi persalinan di RSUD Sungailiat kabupaten Bangka, Bangka Belitung.

Bahan dan Metode: Penelitian ini menggunakan metode retrospektif analitik yang berdesain case control. Populasi semua ibu bersalin postterm di ruang bersalin RSUD Sungailiat dari 1 Juli 2012 - 1 Juli 2015. Sebagai kelompok kasus adalah ibu dengan gagal induksi diambil dengan metode total sampling dengan kiteria inklusi mengalami induksi persalinan gagal dan kriteria eksklusi tidak memiliki data USG trimester 1, tidak memiliki riwayat kontrol kehamilan secara rutin dan ibu dengan komplikasi sebanyak 78 sampel. Sedangkan kelompok kontrol adalah ibu yang mengalami induksi persalinan berhasil diambil dengan metode random sampling perbandingan 1:1. Sumber data dari rekam medis. Analisis data menggunakan Chi-Square dengan tingkat kepercayaan $95 \%$.

Hasil: Penelitian dari 78 sampel yang gagal di induksi 19,2\% berumur $\geq 35$ tahun, $48,7 \%$ primipara, $62,8 \%$ berat badan bayi 23500 gram dan dari 96 sampel jarak kehamilan $47,5 \%$ berjarak $\geq$ 5 tahun. Hasil uji statistik menunjukkan bahwa faktor yang berpengaruh terhadap kegagalan induksi adalah paritas $(\mathrm{P}$ value 0,014 , odds ratio 2,970 ), berat badan bayi ( $\mathrm{P}$ value 0,016 , odds ratio 2,631), jarak kehamilan ( $\mathrm{P}$ value 0,023 , odds ratio 2,993), sedangkan umur ibu tidak memiliki pengaruh yang signifikan dengan $P$ value 0,383 dan odds ratio 2,278.

Simpulan: paritas merupakan faktor utama kegagalan induksi dengan risiko 2,9 kali.

Kata kunci : induksi persalinan, paritas, jarak kehamilan, berat badan bayi

\begin{abstract}
Objectives: to identify factors affecting labor induction failure in Sungailiat General Hospital, District Bangka, Bangka Belitung. Materials and Methods: This is a case control retrospective analytic study. Population of this study was postterm delivering mother at delivery room Sungailiat General Hospital during July 1st, 2012 to July 1st, 2015. Sampling method conducted for case group was total sampling method with labor induction failure as a inclusion criteria, and no data for first trimester ultrasound, didn't have a routine antenatal care history, and maternal complication as exclusion criterias as many as 78 samples. Whereas, control group was women whose underwent a success labor induction used random sampling method with 1:1 ratio. Data source was from medical records. Data analysis was chi square with $95 \%$ confidence interval.

Results: From the 78 samples with labor induction, 19,2 \% was $\geq$ 35 years old, $48,7 \%$ was primiparas, $62,8 \%$ with infant birth weight $\geq 3500$ gram, and from 96 samples, $47,5 \%$ with $\geq 5$ years pregnancy interval. Statistical analysis result showed factors that affecting induction failure were parity ( $\mathrm{P}$ Value 0,014 , odds ratio 2,970 ), baby's weight ( $\mathrm{P}$ Value 0,016 , odds ratio 2,631), pregnancy interval ( $\mathrm{P}$ Value 0,023 , odds ratio 2,993), whereas mother's age did not show significant effect (P Value 0,383 , odds ratio 2,278).

Conclusion: Parity has a 2,9 times risk to develop induction failure.
\end{abstract}

Keywords: labor induction, parity, pregnancy interval, baby's weight

Correspondence: Dina Delvin Anggriani, Perumahan Taman Pesona Bangka Blok B no. 27, District of Bangka, Bangka Belitung, 33211,email: delvin_4@yahoo.com

\section{INTRODUCTION}

Induction of labor is an attempt to stimulate contractions before signs of spontaneous labor, with or without rupture of the membranes ${ }^{1}$ Induction should be performed when mother's and fetus' welfare are threatened by the continuation of the pregnancy. By this labor induction, it is expected that maternal and neonatal morbidity and mortality rate will decrease ${ }^{2 .}$ Induction of labor needs to be done when a pregnancy can cause complications to the mother and fetus. It needs to be done to produce healthy mothers and babies with no complications. However, if labor induction fail then it will be complications in the mother and fetus. The success of labor induction is influenced by two factors: internal and external factors. Internal factors include maternal characteristics (maternal age, parity, space between pregnancies, cervical condition, BMI, gestational age), and fetal characteristics (fetal body weight, presentation, and position of the lowest part). While external factors are such as health worker's throughness and induction method. ${ }^{1.3}$ Increased number of induction failure will increase the number of cesarean surgery and its complication, eventually will lead to increased maternal morbidity and mortality ${ }^{1 .}$

A previous study conducted on 2010 by Nathalie et al in Stockholm, Sweden, found that maternal age, maternal parity and obesity are the strongest factors in the occurrence of cesarean delivery due to induction failure. Another research conducted by Setyorini in Dr. 
Moe-wardi hospitals, Surakarta starting from June 2009 to January 2010, stated that there is no significant association between parity and the success of labor induction using intravaginal misoprostol with $\mathrm{p}$ value of $0.002^{5}$

Based on the data about labor induction in Sungailiat hospitals from 2012 to 2015, labor induction are failed to be decreased in 2013 and in 2014 where the numbers are still over $20 \%{ }^{6-8}$. This rate is still above the tolerable failure rate which is $10 \%{ }^{9}$. This is influenced by several factors that may cause induction failure but those factos are still unknown.

Therefore, it is necessary to study the influence of maternal age, parity, spacing between pregnancies and the baby's weight towards the labor induction failure in Sungailiat Public Regional Hospital.

\section{MATERIALS AND METHODS}

This study was a retrospective study conducted in the delivery room of Sungailiat Regional Public Hospital, Bangka district, using case control study design. Population of this study were all women giving birth in delivery room of Sungailiat Public Regional Hospital during July 1st 2012 to July 1st 2015 with a total of 286 people. The cases group samples were postterm mothers delivering by cesarean section, with indications of failed induction. While the control group samples were postterm mothers delivering by vaginal delivery and labor induction. The sampling technique was total sampling for the case group and 1: 1 ratio for the control group, with the inclusion criterias, such as: went through labor induction procedure, delivered through cesarean surgery (cases group)/vaginal delivery (control group), had complete medical record in Sungailiat Public Regional Hospital year 2012- 2015. While exclusion criteria were: did not have data of first trimester ultrasound and delivered in less than 42 weeks of gestation, did not routinely come for maternal visits, had complications during pregnancy, did not have complete medical record. The research' samples for the cases group were 78 women who met the inclusion and exclusion criterias, and therefore there were 156 samples for cases and control groups. This study used secondary data, where the data was taken from Sungailiat hos-pital's medical record. Data analysis in the study used: (1) univariate analysis that generated frequency and percentage from each variable. (2) bivariate analysis that generated a relationship between dependent and independent variables by using the chi square test. (3) multivariate analysis that generated the effect of any variables and equations by using backward logistic regression method.

\section{RESULTS AND DISCUSSION}

From mother's age variable, it can be seen that at the $\geq$ 35 years old group, the vast majority $(60.0 \%)$ of mothers experienced a failed labor induction, and at the $<35$ years old group, most of the mothers (51.9\%) experienced successful labor induction. $p$ value $=0.383$, indicated that there was no effect of mother's age on the failure of labor induction in Sungailiat Public Regional Hospital during 2012-2015. However, based on the OR value which was $2.278(\mathrm{OR}>1)$, age was a risk factor for the failure of labor induction. This was probably due to the small sample number and the imbalance proportion of mothers age (the amount of mothers aged $\geq 35$ years old in the samples were too small).

Table 1. Effect of mother's age, parity, babies' body weight, distance between pregnancies to the failure of labor induction

\begin{tabular}{|c|c|c|c|c|c|c|c|c|c|c|c|}
\hline \multirow{3}{*}{ Variables } & \multirow{3}{*}{ Group } & \multicolumn{4}{|c|}{ Induction of Labor } & \multirow{3}{*}{$\begin{array}{l}\text { Amo } \\
\text { unt } \\
(\mathrm{N})\end{array}$} & \multirow{3}{*}{$\%$} & \multirow{3}{*}{$x^{2}$} & \multirow{3}{*}{$P$} & \multirow{3}{*}{$\begin{array}{c}\text { CI } \\
95 \%\end{array}$} & \multirow{3}{*}{ OR } \\
\hline & & \multicolumn{2}{|c|}{ Failed } & \multicolumn{2}{|c|}{ Succeed } & & & & & & \\
\hline & & $\mathrm{n}$ & $\%$ & $\mathrm{n}$ & $\%$ & & & & & & \\
\hline \multirow[t]{3}{*}{ Age of Mother } & $\geq 35$ years old & 15 & 60.0 & 10 & 40.0 & 25 & 100 & \multirow{3}{*}{0,762} & \multirow{3}{*}{0.383} & \multirow{3}{*}{$\begin{array}{l}0.678 \\
\text { to } \\
3.866\end{array}$} & \multirow{3}{*}{2,278} \\
\hline & $<35$ years old & 63 & 48.1 & 68 & 51.9 & 131 & 100 & & & & \\
\hline & Amount (n) & 78 & 50.0 & 78 & 50.0 & 156 & 100 & & & & \\
\hline \multirow[t]{3}{*}{ Parity } & Primiparas & 38 & 63.3 & 22 & 36.7 & 60 & 100 & \multirow{3}{*}{6,094} & \multirow{3}{*}{$\begin{array}{c}0,01 \\
4\end{array}$} & 1.245 & \multirow{3}{*}{2,970} \\
\hline & Multiparas & 40 & 41.7 & 56 & 58.3 & 96 & 100 & & & - & \\
\hline & Amount (n) & 78 & 50.0 & 78 & 50.0 & 156 & 100 & & & 4.695 & \\
\hline \multirow[t]{3}{*}{ Babies' body weight } & $\geq 3500 \mathrm{~g}$ & 49 & 59.8 & 33 & 40.2 & 82 & 100 & \multirow{3}{*}{5.784} & \multirow{3}{*}{$\begin{array}{c}0,01 \\
6\end{array}$} & 1.212 & \multirow{3}{*}{2,631} \\
\hline & $<3500$ grams & 29 & 39.2 & 45 & 60.8 & 74 & 100 & & & - & \\
\hline & Amount (n) & 78 & 50.0 & 78 & 50.0 & 156 & 100 & & & 4.380 & \\
\hline \multirow{3}{*}{$\begin{array}{l}\text { Distance between } \\
\text { Pregnancies } \\
\text { (Multipara only) }\end{array}$} & $\geq 5$ years & 19 & 59.4 & 13 & 40.6 & 32 & 100 & \multirow{3}{*}{5.148} & \multirow{3}{*}{0,023} & 1.244 & \multirow{3}{*}{2,993} \\
\hline & $<5$ years & 21 & 32.8 & 43 & 67.2 & 64 & 100 & & & - & \\
\hline & Amount (n) & 40 & 41.7 & 56 & 58.3 & 96 & 100 & & & 7.197 & \\
\hline
\end{tabular}

The $\mathrm{P}$ value: chi-square test, the value $\mathrm{OR}$ : logistic regression 
Based on previous research, older mother ( 235 years) had higher incidence of non-progressive labor, higher requirement of oxytocin in higher doses and longer periods of labor, compared to younger mothers ${ }^{4}$. Labor induction towards women $\geq 35$ years old requires more oxytocin than induction towards women $<35$ years old, and this may cause failed labor induction since labor induction has fixed and established time and dosage.

The results were similar with research conducted by Palomaki, et al, 2011 at Tampere University Hospital, Finland, which showed that with the same study model, using 244 respondents, the $p$ value was 0.61 and the OR was 1 . Therefore, it can be concluded that older mother's age ( $\geq 35$ years) is not a risk factor for induction failure and there is no significant relationship between mother's age and the failure of labor induction ${ }^{10 .}$

In the other hand, a research conducted by Femke Frederiks, Shalem Lee and Gus Dekker (2012) in Lyell McEwin Hospital, Australia showed different result, where older mother's age had influence on the success of labor induction with $\mathrm{OR}=1,052^{11}$. Mothers, above 35 years old, had a risk factor for labor induction. This was similar with other studies, although the study done by MacDorman et al in United States ${ }^{33}$ showing that there was no effect of age on the prevalence of induction ${ }^{12}$.

This does not prove the theory saying that mother with relatively older age (over 30-35 years) and youngest child more than five years old age, will be less likely to be succesfully induced. The cervix becomes stiff and cannot open, so surgery is more frequently performed $^{3 .}$ This may be influenced by differences in the samples number and age distribution of respondents.

In the parity variables, it can be seen that most of the primipara mothers $(63.3 \%)$ experienced a failed induction of labor, while most of the multipara mothers (58.3\%) experienced successful labor induction. $p$ value $=0.014$ showed that parity influence the failure of labor induction in Sungailiat Public Regional Hospital year 2012-2015. The OR value which was 2,970 (OR> 1) proved that parity is a risk factor to the failure of labor induction, so that primipara mothers are at 2.9 times risk of fail induction. The results were similar with the research conducted in Stockholm, Sweden, and Tokyo, Japan, where nulliparous mothers were at five-fold risk of experiencing induction failure compared with multiparous with $\mathrm{OR}=5: 05^{4,13}$

Based on the theory, primipara mothers need more time in passing each laboring phase, therefore it takes longer time to induce than in multiparous ${ }^{1 .}$ Multiparous mothers have more mature cervix for induction compared with primiparous mother, so the induction of primipara mothers need more time and efforts. ${ }^{2}$. Primiparas often require oxytocin augmentation to deliver normally. In primigravidas, the process is preceded by thinning of the cervix prior to the opening, while in multiparous, the process of thinning and opening happen simultaneously ${ }^{4}$.

The fact that primiparous mothers have higher risk of induction failures compared with multiparas is consistent with the theory that the primipara's cervix are still immature, and immature cervix will require a longer time to stimulate through induction. This could cause high failure rate of labor induction ${ }^{1 .}$

Based on the results above, it can be proved that primiparous are at risk of labor induction failure, and it can be influenced by the stiffness of the cervix and the induction time which increases the risk of labor induction failure in primiparous ${ }^{1}$.

On baby weight variables, it can be seen that most $(59.8 \%)$ of the mothers with $\geq 3500$ grams babies' weight, experienced a failed labor induction, while most $(60.8 \%)$ of the mothers with $<3500$ grams babies' weight experienced successful induction of labor. The $p$ value, which was 0.016 , shows that baby's weight affected the failure of labor induction in the delivery room of Sungailiat hospitals during 2012-2015. The OR value, which was 2.631 (OR> 1), proved that baby's weight was a risk factor towards labor induction failure, therefore pregnant women with $\geq 3500$ grams baby's weight were at 2.6 times risk of failed induction.

The results of this study were not consistent with the research conducted by Marroquin et al (2013) in Bronx hospital, Lebanon. This research, which used 76 pregnant women with gestational age of 41 weeks, showed that the babies' body weight did not have significant effect on the labor induction failure with $p$ value $0,11^{14}$.

The results were similar with the results of research conducted by Pavilli, et al (2013) in the S.M. della Misericordia, Perugia, Italy hospital, which showed that there was no effect of the babies' weight towards the failure of labor induction with $p$ value $0.029^{15}$.

From the theory, we knew that the delivery process is influenced by infants' weight. Babies with higher body weight, do not experience engagement to the mother's pelvis. Mothers who give birth with high position of the fetus' head usually have smaller opening of the cervix $^{9}$. This affects the success of labor induction. 
This is supported by the theory that smaller $(<3500$ grams) babies' weight is one of the factors of labor induction success. Mothers with $>3500$ grams babies weight have a tendency to undergo induction failure ${ }^{1}$.

The results of this study proved that higher baby's weight had an influence on the labor induction failure. This may happen because fetus' weight can extend the duration of labor so that labor induction will tend to fail since the time limit for an unsuccessful labor induction is shorter than labor without induction.

In "spacing between pregnancies" variables, primiparous mothers were excluded from the sample, and therefore, the sample numbers were reduced to 96 people. In this variable, most $(59.4 \%)$ of the mothers with $\geq 5$ years spacing from the last pregnancy, experienced a failed labor induction, while most $(67.2 \%)$ of the mothers with $<5$ years spacing from the last pregnancy, experienced successful induction of labor. The $p$ value, which was 0.023 , shows that longer distance from the last pregnancy impact the failure of labor induction in the delivery room of Sungailiat hospitals during 2012-2015. The OR value, which is 2.993 (OR> 1 ), proves that "spacing between pregnancies" is a risk factor towards labor induction failure, therefore pregnant women with $\geq 5$ years spacing from the last pregnancy are at 2.9 times risk of failed induction.

From the theory we know that a mother with $\geq 5$ years of pregnancy spacing usually has cervical state which is similar with primiparas condition or cervical stiffness, and will cause labor induction failure ${ }^{3 .}$ This is consistent with the theory which stated that mothers with the last child's age more than five years old will be difficult to be induced because of the cervical stiffness that could block the cervical opening, making surgery more commonly performed towards them ${ }^{3}$.

Table 2. Multivariate table

\begin{tabular}{clccccc}
\hline & & & & \multicolumn{2}{c}{$\begin{array}{c}\text { 95\% confidence } \\
\text { interval }\end{array}$} \\
\cline { 3 - 7 } & & B & Sig. & $\begin{array}{c}\text { Exp } \\
\text { (B) }\end{array}$ & $\begin{array}{c}\text { Lower } \\
\text { limit }\end{array}$ & $\begin{array}{c}\text { Upper } \\
\text { limit }\end{array}$ \\
\hline $\begin{array}{c}\text { Step } \\
1^{\text {a }}\end{array}$ & $\begin{array}{l}\text { Mother's } \\
\text { age }\end{array}$ & 0823 & 0084 & 2,278 & 0896 & 5,791 \\
& $\begin{array}{l}\text { Parity } \\
\end{array}$ & 1,088 & 0003 & 2970 & 1,462 & 6034 \\
& $\begin{array}{l}\text { Baby's } \\
\text { weight }\end{array}$ & 0968 & 0005 & 2,631 & 1,337 & 5179 \\
& Constants & - & 0000 & 0009 & & \\
\hline
\end{tabular}

The results of this study proved that mothers with $\geq 5$ years spacing between pregnancies have an increased risk for labor induction failure, and it is influenced by the rigid cervical condition. The cervical state of mothers with $\geq 5$ years spacing between pregnancies have similar cervical condition with primiparas (cervical stiffness).
Table 2 illustrates that the risk factors that mostly influence labor induction failure is the parity. Therefore, the equation obtained is $y=(0.823)$ age $+(1.088)$ parity $+(0.968)$ baby's weight.

\section{CONCLUSION}

Primiparas, $\geq 3500$ grams baby's weight, and $\geq 5$ years space with the last pregnancy, are factors of labor induction failure. Primiparas provides the most powerful influence on the labor induction failure with 2.9 times-fold risk.

\section{REFERENCES}

1. Cunningham, dkk. Obstetri Williams. Jakarta: EGC; 2013.

2. Medforth J, dkk. Kebidanan Oxford: Dari Bidan Untuk Bidan. Jakarta: EGC; 2012.

3. Ida Bagus Gede M. Buku Ajar Pengantar Kuliah: Teknik Operasi Obstetri Dan Keluarga Berencana. Jakarta: Trans Info Media; 2012.

4. Nathalie, dkk. Maternal risk factors for postterm pregnancy and cesarean delivery following labor induction. Acta Obstetricia et Gynecologica. 2010;89:1003-10.

5. Setyorini. The Relationship Between Parity with Success of Labor Induction Using Vaginal Misoprostol in RSUD Dr Moewardi Surakarta. Skripsi. Universitas Sebelas Maret Surakarta. 2010.

6. RSUD Sungailiat. Data Ruang Bersalin RSUD Sungailiat Bangka. 2012.

7. RSUD Sungailiat. Data Ruang Bersalin RSUD Sungailiat Bangka. 2013.

8. RSUD Sungailiat. Data Ruang Bersalin RSUD Sungailiat Bangka. 2014.

9. Oxorn, Harry dan Forte, William R. Ilmu kebidanan: Patologi dan Fisiologi Persalinan. Yogyakarta: Yayasan Esensia Medica; 2010.

10. Polmaki, dkk. Prediction of successful labor induction by evaluation of maternal symptoms at an early stage of the misoprostol induction protocol. J. Perinat. Med. 2011;39:299-304.

11. Femke, dkk. Risk factors for failed induction in nulliparous women. The Journal of Maternal-Fetal and Neonatal Medicine. 2012;25(12):2479-87.

12. Guerra, dkk. Factors and outcomes associated with the induction of labour in Latin America. General obstetrics DOI: 10.1111/j.1471-0528.2009. 02348.x. 2009.

13. Wataru, dkk. Prediction model for the incidence of emergent cesarean section during induction of 
Majalah Obstetri \& Ginekologi, Vol. 24 No. 3 September - December 2016 : 79 - 83

labor specialized in nulliparous low-risk women. J. Obstet. Gynaecol. Res. 2011;37(12):1784-91.

14. Marroquin, dkk. Induction of labor at 41 weeks of pregnancy among primiparas with an unfavorable Bishop score. Arch Gynecol Obstet. 2013;288:989-93.
15. Pavilli, dkk. Single indication of labor induction with prostaglandins: is advanced maternal age a risk factor for cesarean section? A matched retrospective cohort study. Jurnal Maternal Fetal Neonatal Medicine. 2013;26(7):665-8. 